\title{
SERGIEJ SKORWID
}

Rosyjski Państwowy Uniwersytet Humanistyczny

Moskwa, Rosja

\section{Code-switching w wypowiedziach użytkowników innosłowiańskich gwar przesiedleńczych w Rosji}

\section{Wstęp}

Od 2009 roku zespół badawczy, złożony z pracowników wielu ośrodków slawistycznych w Moskwie, przeprowadza eksplorację wyspowych gwar innosłowiańskich (czeskich, polskich, ostatnio także ukraińskiej pochodzącej z terenu pogranicznego nad Bugiem) na obszarze Federacji Rosyjskiej. Przedmiotem badań były do tej pory następujące gwary, powstałe w wyniku różnych fal przesiedlenia przodków ich współczesnych użytkowników w drugiej połowie XIX i na początku $\mathrm{XX}$ wieku:

- północnokaukaska gwara czeska (PKCZ), występująca w dwóch odmianach w miejscowościach położonych w Kraju Krasnodarskim oraz Republice Adydei: a) Kiriłłowka pod Noworosyjskiem i Warwarowka pod Anapą; b) Anastasijewka pod Tuapse i chutor Mamacew pod Majkopem (łącznie około 50 użytkowników w wieku od około 60 do około 90 lat);

— zachodniosyberyjska gwara czeska (ZSCZ), notowana we wsiach Nowogradka, Riepinka i Woskriesienka w obwodzie Omskim (w przybliżeniu 25 aktywnych użytkowników w wieku od 60 do 80 lat);

— zachodniosyberyjska gwara polska lub mazurska (ZSP) ze wsi Aleksandrowka w Kraju Krasnojarskim i Znamienka w Republice Chakasji (ponad 60 użytkowników w wieku od około 45 do około 80 lat);

- wschodniosyberyjska gwara polska (WSP) ze wsi Wierszyna w obwodzie Irkuckim (w przybliżeniu 200 użytkowników w różnym wieku — dwie trzecie z 328 mieszkańców wsi); 
— wschodniosyberyjska ukraińska gwara Holendrów (WSU/H/), występująca w miejscowościach Pichtinsk, Sriednij Pichtinsk i Dagnik w obwodzie Irkuckim (około 150 użytkowników od średniego do najstarszego wieku).

PKCZ kształtowała się od końca lat sześćdziesiątych XIX wieku, kiedy po zakończeniu wojny kaukaskiej na terenach wzdłuż czarnomorskiego wybrzeża Kaukazu i na Kubaniu osadzali się między innymi koloniści czescy. Do 1900 roku powstało tu kilka czeskich chutorów w pobliżu Tuapse i później pod Majkopem oraz ponad 10 wsi w okolicach Anapy, Noworosyjska i Gelendżyka; wyłącznie czeskich albo mieszanych (czesko-rosyjskich, z wyjątkiem czesko-polskiej wsi Tekos pod Gelendżykiem). Niedawne nagrania próbek PKCZ ze wsi Anastasijewka, w którą połączono chutory pod Tuapse, a także z chutoru Mamacew dowodzą, że ich pierwsi mieszkańcy stanowili część dalekosiężnej fali kolonizacyjnej, wychodzącej ze Wschodnich Czech, która ogarnęła całą Ukrainę, począwszy od Wołynia, i przesuwała się po lądzie na południowy wschód. Na obszarze między Anapą a Gelendżykiem zamieszkali natomiast koloniści, którzy przybyli (według niezbyt wiarygodnych źródeł statkami przez Odessę) z Południowych Czech, na co wskazują zasadnicze cechy gwary ich potomków.

O pół wieku późniejszą kontynuację wschodnioczeskiej fali kolonizacyjnej stanowiło wtórne przesiedlenie się części mieszkańców osady Čechohrad na Południowo-Wschodniej Ukrainie (obecnie Nowhorodkiwka pod Melitopolem w obwodzie Zaporoskim) na Syberię w związku z polityką agrarną prowadzoną od 1906 roku przez rząd Piotra Stołypina. Na skutek tego w obwodzie Omskim w latach 1911-1913 została założona czeska wieś Nowograd(ka), w której rozpoczęła się oddzielna egzystencja ZSCZ. Charakterystykę tej gwary w zestawieniu z noworosyjsko-anapską odmianą PKCZ podano w pracach autora niniejszego tekstu z $2014^{1}$ oraz 2016 roku$^{2}$; na niektóre osobliwości odmiany tuapsińskiej wskazano w artykule z $2015^{3}$. We wszystkich tych publikacjach poruszane jest również zagadnienie oddziaływania na analizowane gwary języka rosyjskiego (JR) w jego regionalnych odmianach, nieraz z elementami pochodzenia ukraińskiego.

Z polskich gwar przesiedleńczych na terenie Rosji do czasów obecnych z największym prawdopodobieństwem zachowały się tylko dwie. ZSP pojawia się pod koniec lat dziewięćdziesiątych XIX wieku w wyniku wtórnej migracji osadników z Wołynia, wywodzących się z ówczesnych Prus. Wtedy w guberni Jenisejskiej powstała wieś Kożuchowka, później przemianowana na Aleksandrowkę, której

${ }^{1}$ С. Скорвид, Чешские переселенческие говоры на Северном Кавказе и в Западной Сибиpu, „Славяноведение” 1, 2014, s. 44-58.

2 S. Skorwid, Sktadniki tożsamości narodowej potomków polskich przesiedleńców z Mazur w Republice Chakasji i Krasnojarskim kraju FR, „Acta Neophilologica” XVIII, 2016, nr 1, s. 125134.

${ }^{3}$ С. Скорвид, $O$, культурных диалектах” и переселенческих говорах чехов на Черноморском побережье Северного Кавказа, „Славянский альманах” 3-4, 2015, s. 368-382. 
mieszkańcy — Polacy, względnie Mazurzy, i nieliczni Niemcy — od lat pięćdziesiątych następnego stulecia przenosili się z przyczyn ekonomicznych do bogatszej Znamienki (dziś znajdującej się w Republice Chakasji). Pierwsze przybliżenie tej gwary zostało przedstawione w rozprawie doktorskiej Eugeniusza Stupińskiego ${ }^{4}$, a następnie w tekstach Ilji Jegorowa $\mathrm{z}$ lat $2016^{5}$ oraz $2017^{6}$.

Zdecydowanie bardziej znana jest WSP — gwara istniejącej od 1910 roku wsi Wierszyna i dwóch sąsiednich osad (Naszata i Chunzoj). Przesiedleńcy przybywali tu z różnych terenów Zagłębia Dąbrowskiego, znajdującego się na pograniczu Małopolski ze Śląskiem, które wymienia w szczegółowej monografii o mowie Wierszynian Swietłana Mitrenga-Ulitina ${ }^{7}$. Występujące w WSP systemowe cechy „dialektu małopolsko-śląskiego" zostały opisane w publikacjach Nataliji Ananiewy ${ }^{8}$. W ostatniej z nich ${ }^{9}$ przedstawiono również osobliwości zachodniosyberyjskiej odmiany polszczyzny kresowej, którą posługiwano się — choć widocznie w coraz węższym zakresie - przez prawie 100 lat we wsi Białystok w obwodzie Tomskim. W pierwszych dziesięcioleciach XXI wieku udało się ją zarejestrować już tylko w postaci idiolektu jedynej żyjącej użytkowniczki — pani Marii Markisz (ur. 1928).

Nagrane w latach 2016-2017 przez wrocławską badaczkę historii Polaków na Syberii Agnieszkę Kaniewską oraz autora niniejszego artykułu rozmowy z panią Markisz i o rok młodszą mieszkanką tejże miejscowości - panią Anną Lekariewicz (która po polsku nie mówi, czyta jedynie modlitwy), wskazują zresztą na to, że syberyjski Białystok od początku był wsią językowo mieszaną, polsko-białoruską z narastającą infiltracją JR.

Oto jak wypowiada się (po rosyjsku) o dawnej sytuacji językowej w rodzimej wsi pani Lekariewicz:

я чит' аю по_п'ольски / м'ама / 'ета / науч'ила мин'я па_п'ольски чит'ать // а та'к нихт'о_в_нас уж'е тип'ерь не_чит'ает / адн'а 'я // адн'а_вот у॰н'ас / ан'а по_п'ольски / ф_симь'е ани_фс'е

${ }^{4}$ E. Stupiński, Polszczyzna okolic Krasnojarska, rozprawa doktorska napisana w Katedrze Dialektologii Polskiej UŁ, Łódź 2008.

${ }^{5}$ И. Егоров, Польский переселенческий говор в Республике Хакасия и в Красноярском крае $P \Phi$, ,Slavia Occidentalis” 73/1, 2016, s. 45-59.

${ }^{6}$ I. Jegorow, Zur Sprachsituation und ethnischen Identität in zwei von den historischen ostpreußischen Masuren besiedelten Dörfern in Sibirien, [w:] Junge Slavistik im Dialog VI. Beiträge zur XI. Internationalen Slavistischen Konferenz, red. A. Weigl et al., Hamburg 2017, s. 97-105.

7 S. Mitrenga-Ulitina, Język polski mieszkańców wsi Wierszyna na Syberii, Lublin 2015, s. 26.

${ }^{8}$ Н. Ананьева, Морфология глагола в польском говоре деревни Вершина Боханского района Иркутской области, [w:] Исследования по славянской диалектологии, т. 16, red. Л. Калнынь, Москва 2013, s. 203-210; еадет, Типология польских говоров Сибири и результаты их контактов с русским идиомом, [w:] Славянское языкознание. ХV Международный съезд славистов. Минск, 2013 г. Доклады российской делегации, red. А. Молдован, С. Толстая, Москва 2013, s. 467-478.

${ }^{9}$ Wcześniej również w N. Ananiewa, Zróżnicowanie pokoleniowe polskich gwar kresowych (wybrane zagadnienia), „Gwary Dziś” 3, 2006, s. 96-97. 
үавар'или / Михн'я фам'илия былў'а / ан'и... й'их_была в'осе-.. с'емь бр'атьев нав'ерна / и_вот_ан'и фсе па_п'ольски разүав'аривали // Ян'ушка фам'илия был'а / т'оже па_п'ольски разүав'аривали // а н'аши // и б'абушки [...] р'аньше вапщ'е разүав'аривали / щит'ай_вот ст'ар'ие_эти / то_вапщ'е б'ольше па_белар'уски.

Natomiast z wypowiedzi pani Markisz wynika, że nawet w jej rodzinie były w użyciu dwa języki; tym niemniej polszczyzna typu kresowego, a więc też mieszana, pozostawała dla niej podstawowym kodem, dopóki miała rozmówców:

ja po pol'sku gadam a č'ýtat' n'e nauč'ilas' [...] ja juž dużo i zapomn'aư⿱ n'i ma s k'im s'e rozmav'ac' / jag byl'i ješ'č'e tok rozmav'ałas' / a teras n'i ma s k'im [...] u n'az'10 była mama s Pol'šy / jo pšyv'ezl'i s'ud'a / tšy rok'i było mam'e / to my v domu z mamo po pol'sku gadal'i / my d'et'i nas č’'etv'era było / i my po pol’sku / a s tatem my pou rusku gadal'i [...] ja pošła f škołe / uč'ýt'el' mn'e zadał st'ixatvar'en'iie uč'it'/ ja połov'ine vyuč'iła połov'ine n'e / a mn'e po rusku było ćenško gadac' / vot un / nada było mn'e jem'u st'ixatvar'en'iie rospov'ez'ec' / ja połov'ine rospov'ez'ała jemu a połov'ine gadam a ja dal'ej n'e v'im / po pol'sku.

Nieco odmienna była początkowa sytuacja w istniejących od 1912 roku wsiach innej grupy przybyszy z Kresów na Syberię — tak zwanych Holendrów. Ich pierwsi osadnicy wywodzili się z kolonii nad Bugiem w byłej guberni Grodzieńskiej Neudorf-Neubrow i innych, które uważano za niemieckie. Ponadto przedstawiciele tej grupy etnicznej byli wtedy na pewno w znacznym stopniu spolonizowani (polszczyzna kresowa musiała być odbierana przez nich jako język prestiżowy), lecz jeszcze na Kresach przyjęli jako swoją gwarę otoczenia ukraińskiego. Świadczą o tym między innymi nazwy ich nowo powstałych w guberni Wołyńskiej wsi Zamust' eče i N' ovyny, które przesiedleńcy nieoficjalnie nadali również swoim osadom na Syberii. Dotychczas ślady polszczyzny kresowej dostrzegano w dykcji syberyjskich Holendrów, nie tylko kiedy czytali przywiezione z kolonii nadbużańskich polskie książki (wymawiane [ks'onšk'i]) do nabożeństw ewangelickich, lecz także w brzmieniu niektórych zachowanych w ich mowie polskich słów (np. [3'en'kuju], [3'is'], [c'otka], [koc'uba]). Poza tym w codziennej komunikacji starszych (w wieku powyżej 60 lat) członków tej wspólnoty używana jest swoista gwara typu zachodnioukraińskiego, ulegająca mocnemu wpływowi JR. Porównaj wypowiedź pani Galiny Ludwig (ur. 1965):

unot ja sk'il'ko sł'uxaju jag guv'or'et' č́isto ukr'ajinc'i [...] unot xot' pu_tiliv' izorovy st'uxaješ, to // v_nas mn'yho šo ne sofpad'aje // on'y mn'oho tak'ix słou huv'or'et' šo // nu v_nas ne tak // a u_n'as [...] s p'ol'sk'im mn'yho / nu i // a pr'osto uot tak''ij uot jaz'bk // mы d'oma fs'o huv'orymo pu_sv'ojimu / nu tak pryv'ykl'i bo / m'ama r'an'še tak huvur'yli / i bat'k'i_našy tak huvur'yli / i my tak / fs' 'ako huv' orymo.

10 Tu i dalej w wypowiedziach polskich i czeskich, włączając w to wstawki nawet pojedynczych wyrazów czy zdań, miejsce akcentu zaznacza się jedynie wtedy, kiedy jest ono odmienne od prawidłowego w danym języku (na przedostatniej sylabie w polskim, na pierwszej w czeskim), przede wszystkim w wyrazach zapożyczonych z JR. 


\section{Wybór kodu językowego}

W kontakcie z dwujęzycznymi członkami badanych społeczności osoby przeprowadzające wywiady na ogół unikały JR, zachęcając rozmówców do prowadzenia dialogu w gwarze (sami zaś posługiwali się literacką lub potoczną odmianą odpowiedniego innosłowiańskiego języka, częściowo dostosowując ją do dialektu). Jeżeli niektórzy respondenci odmawiali wypowiadania się w gwarze, składały się na to cztery czynniki, często łączące się między sobą w różnych kombinacjach:

a) utracona lub słaba umiejętność mówienia gwarą;

b) obcość eksploratora;

c) nieutożsamianie się z używanym przezeń językiem;

d) postrzeganie gwary jako wyłącznie swojej, nieprestiżowej na zewnątrz odmiany językowej, lęk przed ośmieszeniem się lub inny strach „zakodowany”.

Oto typowe reakcje takich rozmówców na prośbę o odtworzenie mowy, która brzmiała, względnie wciąż brzmi, w ich komunikacji rodzinnej:

ab) Polka — pani Józefa Sołodownikowa, z domu Maliborska (ur. 1928), z polsko-czeskiej wsi Tekos pod Gelendżykiem: „м'ожит / зн'аите / 'если бы я / ну с_в'ами зн'алась // а т'ак я к'ак_та н'ервничию / я ничев'о...”. Użycie przez nią $\mathrm{w}$ wypowiedzi rosyjskiej czasownika зналась ma prawdopodobnie korzenie polskie (= znata się). W trakcie rozmowy przypomniała sobie nawet całe zdanie, które miał powiedzieć po polsku sąsiad, oburzony kradzieżą plonu z pola: ,jed-

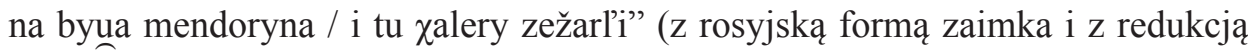
samogłoski w wyrazie cholery), niezbyt dokładnie tłumacząc go na JR: „адн'а памид'орина сп'елая был'а / и ах'отники шл'и // и т'у вз'яли"; a także wiejskie przysłowie czeskie — komiczne określenie tej dwuetnicznej osady: „púl Poláka, púl Čecha / rostrhaná punčoða".

abc) Niemka — pani Wiera Rudenko (ur. 1953) ze Znamienki w Chakasji:

ну вот т'ак / tak gadal'i_vot / как // а ч'истый_вот п'ольский [...] как вот я быy̆'а в_Гирм'ании_вот / сў'ышала пал'якъф [...] фсё равн'о у_н'ас / ни_так'ой... <Osoba przeprowadzająca wywiad: No to jak? Jek, jek u was gadali?> jek, jek / ag'a // vot gadal'i / вот на_'этам язык'e i gadal'i // po_polsku // c_paд'итилями / ан'и_вот по_м'оему кан'ешно т'аг гавар'или / а пот'ом уже фсе

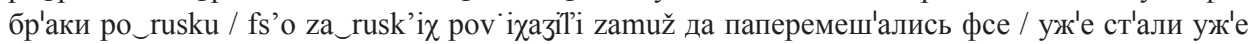
кан'ешно фсе свой яз'ык забыв'ать [...] с_сеёстрами мы фсё равн'о д'ома мы фсё равн'о gadal'i т'аг_же между_соб'ой / и щ'ас_даже 'если фстреч'аемся / то нам л'екче таг гавар'ить [...] mauo gadam'i tak / to juz zabač' 'ujem 'i.

bd) Holender — pan Iwan Kunc (ur. 1936) z Pichtinska w obwodzie Irkuckim: „my nyč'oho tak / kak skaz'aty // nu 'eto ne hol'endrousk'ij a хахл'ацкий яз'ык / да и фсё /// а хахл'ацкий kak skaz'aty / украй'инский но в гр'упшъй абраб'отки / вот так // я и украй'инскава / ч'исто украй'инскава вам ни / смаг'у...”. Na namowę córki „huvur'y pu_sv'ojemu / jak ty huv'oryš / i fs'o” pan Kunc odparł: „,нy как я // я фсегд'а таг гавар'ил”. Niechęć do mówienia własną gwarą z powodu po- 
strzegania jej jako nieprestiżowej, przynajmniej wśród Holendrów syberyjskich, jest typowa szczególnie dla mężczyzn.

Jednakże nawet kiedy respondent zdecydowanie woli JR, jeżeli w jego wypowiedzi pojawiają się świadome lub nieświadome wtrącenia innosłowiańskie (oprócz cytatów typu ,jedna byua mendoryna”), można mówić o przełączaniu albo mieszaniu kodów językowych. Te dwa pojęcia — code-switching i code-mixing w oparciu o prace Petera Auera ${ }^{11}$ oraz Pietera Muyskena ${ }^{12}$ — rozróżnia i całkiem trafnie stosuje przy opisywaniu zjawisk bardzo podobnych do występujących w omawianych wspólnotach wyspowych na terenie FR Michał Głuszkowski w artykule o rosyjsko-polskim bilingwizmie staroobrzędowców w regionie suwalsko-augustowskim. Według przyjętych przezeń założeń teoretycznych przełączanie kodu językowego to uświadomiona zmiana międzyzdaniowa czy też zachodząca na styku zdań składowych lub fraz wewnątrz zdania prostego (,,vs'o pav'ała / to

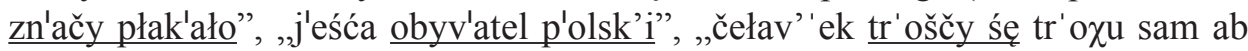
s'eb' 'a"13); dopiero „w następnym stadium przełączanie kodów ustępuje miejsca ich nieuświadomionemu mieszaniu, które $\mathrm{w}$ efekcie prowadzi do amalgamacji i powstania nowego mieszanego kodu"14. Zgodnie z tym ujęciem z powyższych przykładów code-switching demonstrowałby drugi komunikat (pani Rudenko), code-mixing zaś trzeci (pana Kunca). Oczywiście, w obydwu głównie rosyjskojęzycznych wypowiedziach chodzi tylko o wstawki gwarowe.

Znacznie szerszy zakres zjawisk podpadających pod dyskutowane kategorie obserwuje się, gdy respondenci zgadzali się na prowadzenie dialogu w gwarze pomimo przypadków niezrozumienia odmiany językowej używanej przez eksploratora (wtedy rolę pomocniczą mógł pełnić JR). Trzeba przy tym zaznaczyć, że dokonany przez osobę, z którą przeprowadzano wywiad, wybór gwary jako podstawowego kodu niekiedy utrudniał mu przynajmniej szybkie jego przełączenie w razie potrzeby. Oto jak ,przetłumaczyła” na prośbę badaczki, niewładającej językiem czeskim, odśpiewaną przed chwilą piosenkę użytkowniczka ZSCZ pani Anastasia Vondra (1937-2015) z Riepinki w obwodzie Omskim:

$<$ Osoba przeprowadzająca wywiad: А на русский можете песню перевести?> — nu / blísko lesejka rostla unosika / бл'иско л'еса растл'а ас'ина // tam př́i- / přísahala [...] falešna d'eunka př́sahala klukoj / přis'’ahu што в'ерная ем'у б'удет // a on d'iš s_vojni přišel po_n'i se ptal <Osoba przeprowadzająca wywiad: А он не пришёл?> — a já to po_česki povidám?

W tym fragmencie międzyzdaniowemu przełączeniu kodu z gwary na JR to-

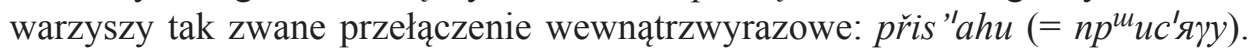

${ }^{11} \mathrm{P}$. Auer, From code-switching via language mixing to fused lects: toward a dynamic typology of bilingual speech, ,The International Journal of Bilingualism” 3, 1999, s. 309-332.

12 P. Muysken, Bilingual Speech: a Typology of Code Mixing, Cambridge 2000.

${ }^{13} \mathrm{~W}$ ostatnim przykładzie — i jemu podobnych — uświadomiony charakter zmiany języka można byłoby kwestionować.

${ }^{14}$ M. Głuszkowski, Przełączanie kodów czy kod mieszany? Aktualny stan bilingwizmu staroobrzędowców w regionie suwalsko-augustowskim, ,Acta Baltico-Slavica” 36, 2012, s. 29-30. 
Podobne zjawisko można zauważyć w odpowiedzi mieszkanki wsi Znamienka w Chakasji - pani Tatiany Winnik, z domu Bortnickiej (ur. 1956), na pytanie „Co Pani mąż robił w szkole?” - „уч'итель // f''iz'ik'e pše- / препадав'ал”. Obszerny wywiad z tą użytkowniczką ZSP, która od razu chętnie zaakceptowała prowadzenie rozmowy w języku polskim (z jej strony w gwarze), obfituje ponadto w rozmaite inne typy zmiany kodu językowego, znajdujące odpowiedniki w nagraniach gwar innosłowiańskich $\mathrm{z}$ innych terenów, co pozwala na zaprezentowanie na nowo zasadniczego zagadnienia związanego $\mathrm{z}$ tą stroną dwujęzyczności przedstawicieli badanych grup.

\section{Code-switching, code-mixing czy interferencja międzyjęzykowa?}

Przyjrzyjmy się najpierw przyczynom przechodzenia rozmówców z gwary na JR w trakcie wywiadu. Pomińmy jednocześnie przypadki, kiedy informator przechodzi na JR w celu przekazania komunikatu trzeciej osobie, która nie rozumie gwary ${ }^{15}$. W takich wypadkach często w ogóle nie chodzi o przełączenie kodu w wypowiedzi gwarowej, tylko o rozpoczęcie odrębnej wypowiedzi w JR. Tak wspomniana pani Tatiana Winnik odzywa się po rosyjsku do wnuka, którego okrzyki „гавар'и па_нарм'альнаму!” przeszkadzają w rozmowie. Ciekawe jest jednak, na co się powołuje:

Вл'адик / вн'учек / ид'и_ка сюд'а / я тиб'е раскаж'у // штоб он ка_мн'е не_пристав'ал / да? // вот 'эта вот с_Маскв'ы при'ехали [...] ан'и ни_ум'еют па_р'уски гавар'ить // ан'и ум'еют

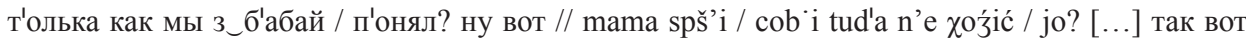
па_нарм'альнаму / 'эта и б'удет т'ак как мы мы 3_б'абай.

Niezależnie od tego, czy rozmówczyni naprawdę wierzyła, że osoby przeprowadzające wywiad, które przyjechały z Moskwy, nie mówią po rosyjsku, w cytowanym fragmencie przemawia ona też do nich w tym języku, a później, wracając do poprzedniej wypowiedzi, znów w gwarze. Również po rosyjsku ich przywitała, mówiąc: „прахад'ите / прахад'ите! [...] davajta o tu poš’ésim / o tu”, co należy uznać za cytatowe użycie formuły, która jest jej znana z etykiety rosyjskiej, czyli za przejaw tak zwanego tag switching.

Charakter cytatów mogą mieć także wstawki rosyjskie w wypowiedziach opisujących sytuacje spoza sfery komunikacji rodzinnej, obsługiwanej przez dialekt. Porównaj opowiadanie pani Winnik o nagrodzeniu jej ojca orderem Lenina:

tata zarobž'uu 'ордин Л'енина / sama lepša nagrada / unot [...] za_to co robž’uu na_kambajn'e /

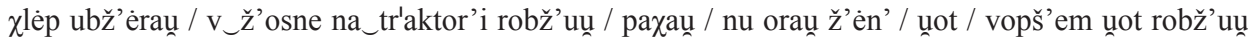

15 Oczywiście, zarówno osób przeprowadzających wywiad, jak i obecnych podczas konwersacji trzecich osób może być więcej. 


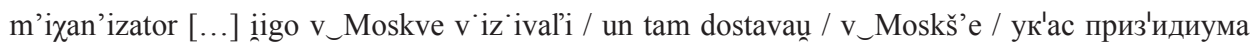

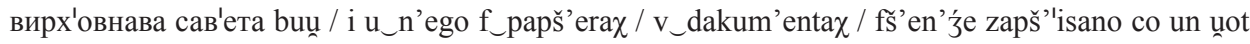
награжд'ённый.

Bezpośrednimi cytatami są w tej narracji nazwy samego orderu i dekretu, na mocy którego został on nadany, oraz wyraz награжд'ённылй, który występował, choć zapewne nie w tej formie, w dokumentach. Innego rodzaju są łączące się z gwarową formą czasownika robić wyrazy m'ixan'izator, na_kambajn'e, $n a \_t r$ 'aktor'i (nie „mechanizator”, „na kombajnie”, „na traktorze”), nagrada w połączeniu ze zrusyfikowaną formą stopnia najwyższego przymiotnika i inne. Chodzi tu o wtrącenia z JR, do których informatorka ucieka się, kiedy po pros-

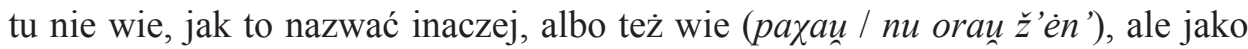
pierwsze przychodzi jej do głowy słowo rosyjskie, w danym kontekście zresztą użyte w postaci spolszczonej. Ponieważ we wszystkich takich przypadkach trudno jednoznacznie odpowiedzieć na pytanie, czy użytkownicy gwary uświadamiają sobie (i jeśli tak, to w jakim stopniu), że przełączają kod językowy, należałoby tu mówić raczej o mieszaniu kodów. W każdym razie można jednak przypusz-

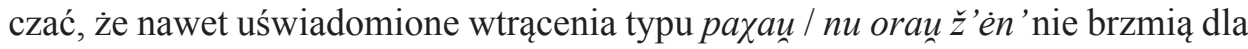
nich w momencie wypowiadania bynajmniej obco. Jeszcze bardziej zadomowione w gwarze są zapożyczone słowa dyskursywne, typu vopš' 'em, unot - ich używanie, jak się zdaje, nie ma w ogóle nic wspólnego z code-switching ani z code-mixing.

Analogiczne przykłady można przytoczyć także z wypowiedzi przedstawicieli innych badanych wspólnot. Porównaj bardzo podobne do siebie wspomnienia z lat młodzieńczych, wypowiadane przez: a) Polaka z Wierszyny — pana Walentego Wiżentasa (ur. 1929), b) Czecha z Anastasijewki pod Tuapse — pana Vladimira Kutnohorskiego (ur. 1946) i c) Holendra ze Sriedniego Pichtinska — pana Piotra Ludwiga (ur. 1951), odpowiednio w WSP, PKCZ i VSU/H/ z mnóstwem rusycyzmów $\left({ }^{\mathrm{R}}\right)$ oznaczających realia, dla których $\mathrm{w}$ gwarach tych nie powstały — albo, jeśli istniały, to zanikły — własne środki leksykalne, oraz innych często przenikających do nich wtrąceń z JR ${ }^{16}$ :

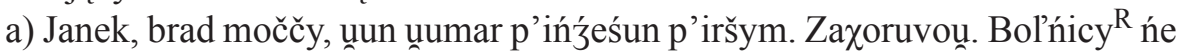

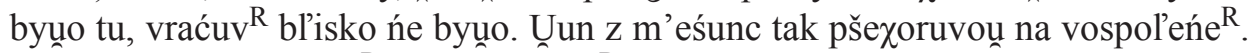
[...] Tero to žyź možno ${ }^{\mathrm{R}}$, no fs'o rovno ${ }^{\mathrm{R}}$ luźum śe ńe podobo. A jag my pšoźi žyl'i. Ńi śv'atu ${ }^{\mathrm{R}}$, el'ektr'ićestva ${ }^{\mathrm{R}}$ ńe byuno, pšy nafće my uxucyl'i śe, cytal'i i pisal'i ${ }^{17}$;

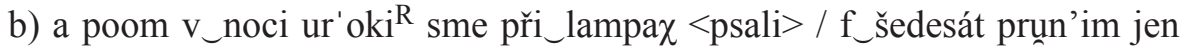
sv'et $^{\mathrm{R}}$ nám dali / el'ektr' 'ičestvo ${ }^{\mathrm{R}}$ jen $\mathrm{f} \_$šesát prun 'ím roku se pojavilo ${ }^{\mathrm{R}}$ tadi / póz'd'e / uš já sem bil ve třet’im kuasu ${ }^{R} /$ uno takl'en sme žily;

16 Takich jak liczebnik złożony w ostatnim fragmencie (przy czym jego użycie pociąga za sobą przełączenie kodu).

17 S. Mitrenga-Ulitina, op. cit., s. 181. 
c) V_nas l'ampočka ${ }^{R}$ t'aja zahor'ila s'e / ф_шыис'ят сидьм'ом гад'y // до_шыис'ят сидьм'ова г'ода в_нас л'ампы б'ыли. [... я я к'ончиў шк'олу в'осемь кл'асоў pry_ł'ampax.

Mniej liczne nagrania konwersacji użytkowników gwar między sobą, bez udziału badacza, ujawniają $\mathrm{w}$ zasadzie te same typy mieszania czy też przełączania kodów zarówno w kierunku, ,gwara $\rightarrow$ JR”, jak i w odwrotnym, z tym że procesy te niekiedy wydają się zupełnie niemotywowane i niczym nieregulowane. Porównaj rozmowę przy stole w czeskiej Nowogradce w obwodzie Omskim, która rozpoczyna się w JR z wtrącaniem pojedynczych elementów ZSCZ, potem uczestnicy wymieniają repliki w obydwu językach, wreszcie zaś w wypowiedziach tych samych osób obserwuje się (cytatowe) przełączenie kodu pomiędzy zdaniami oraz przełączanie — czy też mieszanie — kodów wewnątrz zdania złożonego i prostego nawet na styku podmiotu z orzeczeniem:

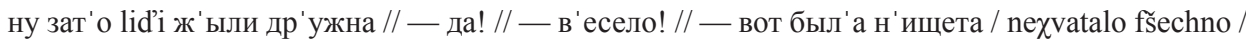

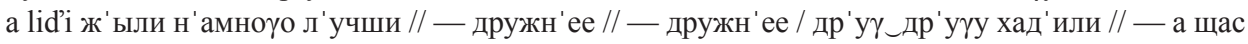

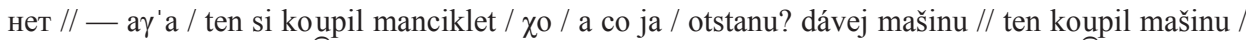
dávej ja ešče lepši mašinu [...] ukážem že já žiju lepši než druhí žijou// — а вот дав'айте у ко ${ }^{\gamma}$ о маш'ыны мы // - б'удем друж'ыть у ко ${ }^{\gamma}$ о маш'ыны $[\ldots]$ а 'если у мин'я ничи ${ }^{\prime}$ о нет [...] што тип'ерь? а н'адо общ' ение! // — vedle chát'e proxázej mimo / ой ходь_бы к_нам нэ зашл'и / našlapou tadi // — ubirat nada / da // — da ji nada potom úhoš'at [...] — как р'аньше б'ыло / да? // порос'ёнка 'эта / zabijoư / sebíraj se roctv'en'ik'i // м' ожна пад'умать že sn'ed'í [...] адн 'ако нет / sebíraj se zrounna / tam bratři или там хто / аү'а // и ж'оны přišli // nawařej / d'elaj tu / po_česki itrn'ici да ўс' якие 'эти // i tadi vařej tadi pol'oụku řikali nada / aha // — nu kolbasi vařili туд'а_сюд'а [...] — да! — и с'ало / sádlo přetopjej i fřecko ud’elaj / i potom sedaj za stúl [...] — и хараш' o! // fs'o za jeden den'.

Przy analizie takich wypowiedzi wielokrotnie nasuwa się pytanie, czy w ogóle warto starać się rozróżniać code-switching i code-mixing, szczególnie wewnątrz zdania prostego. W ujęciu Głuszkowskiego zdania typu „порос'ёнка 'эта / zabijoư⿱ pod przełączanie kodu, lecz w drugim przypadku przejście rozmówczyni z JR na ZSCZ jest dla niej zdecydowanie nieświadome. Także w tym przypadku należałoby mówić raczej o mieszaniu kodów typu wtrącającego, gdy „element kodu $\mathrm{L}_{2}$ [...] jest włączany w ramy utworzone przez bazowy język danej wypowiedzi"18, tyle że w przytoczonej konwersacji rosyjsko-czeskiej trudno określić, który język jest bazowy $\left(\mathrm{L}_{1}\right)$.

Tego rodzaju wewnątrzzdaniowemu mieszaniu kodów jest $\mathrm{w}$ istocie bardzo bliskie tak zwane wewnątrzwyrazowe przełączenie kodów, typu „f'iz'ik'e pše- / препадав'ал" (z wypowiedzi użytkowniczki ZSP), jakie może zachodzić nie tylko na styku przedrostka i rdzenia, lecz także przy przyłączeniu końcówki. Porównaj fragment dialogu użytkowniczki PKCZ z Kiriłłowki pod Noworosyjskiem — pani Jevgenii Ružečko (ur. 1926) — z odwiedzającą ją sąsiadką, która nie chce siedzieć

18 M. Głuszkowski, op. cit., s. 29. 
przy klimatyzacji, bo tam wieje: „nefouká / vot já t’e posad'ím hd’e nefouká [...] a diš tak já to vыkl'učím" (= выюлючи:м). Zapożyczony z JR czasownik выключumь, wymawiany do ostatniej zgłoski rdzenia po rosyjsku, przybiera tu czeską końcówkę 1 osoby liczby pojedynczej. Takich przypadków w nagraniach rozmów z członkami wszystkich eksplorowanych społeczności jest wiele. Jak je oceniać?

Trzeba przyznać, że praktycznie cały zasób rosyjskich jednostek leksykalnych, które są znane użytkownikom badanych dialektów z regionalnej odmiany mówionej czy z „wyższych” wariantów JR — łącznie z kolokacjami aż do tworzenia zdań, nieraz z zachowaniem ich rosyjskich form gramatycznych i niezmienionej postaci fonetycznej - stanowi nieodłączną część składową ich gwary. Do tego źródła rozmówca zawsze może sięgnąć, najczęściej wcale nie uświadamiając sobie, że są to środki zapożyczone, i nie odbierając ich jako elementy obce. Stąd wniosek, że w wypadkach tak zwanego wewnątrzwyrazowego przełączania kodu chodzi raczej o przejaw interferencji międzyjęzykowej. Mieszanie kodów to zresztą tylko szczególny — jakkolwiek odrębny — przypadek tejże interferencji.

\section{Uwagi końcowe}

Podsumowując, można stwierdzić, że ze względu na obecność bardzo licznych przejawów zarówno code-switching, jak i — w szczególności — code-mixing w wypowiedziach użytkowników eksplorowanych gwar odmiany językowe, którymi się posługują, właściwie trzeba uznać za kod mieszany, jak M. Głuszkowski thumaczy stosowany przez P. Auera termin fused lect. Autor cytowanego artykułu o bilingwizmie polskich starowierców jest bardziej ostrożny w swoich wnioskach, orzekając: „Niektóre teksty mówione [...] noszą znamiona kodu mieszanego, ale określenie tym mianem całego systemu byłoby nadużyciem" ${ }^{\prime 19}$.

Jeżeli chodzi o przesiedleńcze dialekty innosłowiańskie w Rosji, to sytuacja jest odmienna - system każdego z nich w wyniku stałego kontaktu z JR stopniowo uległ procesowi hybrydyzacji, który (w odróżnieniu od procesu adaptacji rusycyzmów), приводит к восприятию системой идиома-реципиента черт идиома-донора"20. Użytkownicy gwar są w pełni świadomi owej hybrydalności, o czym wymownie świadczą ich wypowiedzi na ten temat, z których trzy należałoby przytoczyć na zakończenie:

a) państwo Jevgenia (ur. 1926) i Leonid Ružečko (1927-2014) z Kiriłłowki pod Noworosyjskiem (PKCZ): <Osoba przeprowadzająca wywiad: Mluvíte mezi sebou česky?> L.R.: mez(i) sebou jo, no ale u_nás uš je os 'obej jazik českej // on

19 Ibidem, s. 37.

20 Д. Поляков, Интерференционные процессы и гибридизациия в переселенческих говорах, [w:] Гибридные формы в славянских культурах, red. Н. Злыднева, Полимедиа, Москва 2014, s. 134. 
je uš pře- // JR: mi to máme už zmíxaní fšecko - L.R.: uš tam je víc ruskího neš českího v`našem rozh 'ovoru;

b) pani Taisja Szyszko (ur. 1956) ze Znamienki w Chakasji (ZSP): m`i gadam ‘i po_svojimu po_polsk'emu [...] nu a tutaj m 'i š’e opš'č'am i jus tak jek / z_rusk'em“i po_rusk'i // i m’i svoj jenz'ik_is pš'evroćil'i / tera on jus n'e

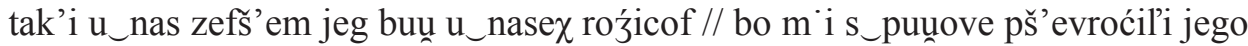
na_rusk'i jenz'ik i suova v'ikrenćil'i po_svojemu;

c) pani Walentina Ginborg, z domu Kunc (ur. 1930) z Pichtinska w obwodzie Irkuckim (WSU/H/): п' омню/v_men' e sus' 'itka pryšł' a / а у_н' ей был' а вн 'учка [...] N'ad'u / N'ad'u / пайд'ём do_d'omu! [...] u_n'as tag vže ne huv'o<ret'> / my bul'ž_že pu_r'usk'i / pu_r'usk'i // i to šo ne č' isto r'usk'ij no tak // fs'o už'e per'em' 'ešanaje.

\section{Bibliografia}

Ananiewa N., Zróżnicowanie pokoleniowe polskich gwar kresowych (wybrane zagadnienia), „Gwary Dziś" 3, 2006.

Auer P., From code-switching via language mixing to fused lects: toward a dynamic typology of bilingual speech, „The International Journal of Bilingualism” 3, 1999.

Głuszkowski M., Przełączanie kodów czy kod mieszany? Aktualny stan bilingwizmu staroobrzędowców w regionie suwalsko-augustowskim, „Acta Baltico-Slavica” 36, 2012.

Jegorow I., Zur Sprachsituation und ethnischen Identität in zwei von den historischen ostpreußischen Masuren besiedelten Dörfern in Sibirien, [w:] Junge Slavistik im Dialog VI. Beiträge zur XI. Internationalen Slavistischen Konferenz, red. A. Weigl et al., Verlag Dr. Kovač, Hamburg 2017.

Mitrenga-Ulitina S., Język polski mieszkańców wsi Wierszyna na Syberii, Wydawnictwo Uniwersytetu Marii Curie-Skłodowskiej, Lublin 2015.

Muysken P., Bilingual Speech: a Typology of Code Mixing, Cambridge University Press, Cambridge 2000.

Skorvid S., Czech immigrant dialects in the Northern Caucasus and Western Siberia, „International Journal of the Sociology of Language" 238, 2016.

Skorwid S., Składniki tożsamości narodowej potomków polskich przesiedleńców z Mazur w Republice Chakasji i Krasnojarskim kraju FR, „Acta Neophilologica” XVIII, 2016, nr 1.

Stupiński E., Polszczyzna okolic Krasnojarska, praca doktorska napisana w Katedrze Dialektologii Polskiej UŁ, Łódź 2008.

Ананьева Н., Морфология глагола в польском говоре деревни Вершина Боханского района Иркутской области, [w:] Исследования по славянской диалектологии, t. 16, red. Л. Калнынь, Институт славяноведения РАН, Москва 2013.

Ананьева Н., Типология польских говоров Сибири и результаты их контактов с русским идиомом, [w:] Славянское языкознание. XV Международный съезд славистов. Минск, 2013 г. Доклады российской делегации, red. А. Молдован, С. Толстая, Индрик, Москва 2013.

Егоров И., Польский переселенческий говор в Республике Хакасия и в Красноярском крае РФ, „Slavia Occidentalis” 73/1, 2016.

Поляков Д., Интерференщионные процессы и гибридизаџия в переселенческих говорах, [w:] Гибридные формы в славянских культурах, red. Н. Злыднева, Полимедиа, Москва 2014. 
Скорвид С., Чешские переселенческие говоры на Северном Кавказе и в Западной Сибири, „Славяноведение” 1, 2014.

Скорвид С., O „культурных диалектах” и переселенческих говорах чехов на Черноморском побережье Северного Кавказа, „Славянский альманах” 3-4, 2015.

\section{Code-switching in utterances of speakers of alien Slavic immigrant dialects in Russia}

Summary

The paper deals with the phenomenon of the so called code-switching which accompanies the existence of Czech and Polish immigrant dialects spoken in Russia that are located in the Northern Caucasus and in Siberia, as well as originally West Ukrainian patois of East Siberian Holenders. The author compares different types of code-switching and code-mixing seen in their native speakers' utterances with the situation observed among Russian Old Believers in Poland by Michał Głuszkowski (2012) and, in contrast to him, widens the scope of the latter term. It is shown that in all probability in the case of the examined immigrant dialects in Russia in their present state due to regular code-mixing there have been developed fused lects as defined by Peter Auer (1999).

Keywords: Slavic immigrant dialects in Russia, language contact, interlanguage influence, code-switching and code-mixing, fused lect

\section{Переключение кодов в речи носителей инославянских переселенческих говоров в России}

Резюме

В статье рассматривается явление так называемого переключения кодов, какое сопровождает бытование чешских и польских переселенческих говоров в России, локализующихся на Северном Кавказе и в Сибири, а также западноукраинского по происхождению говора восточносибирских голендров. Различные типы переключения и смешения кодов в высказываниях их носителей сравниваются с ситуацией, которую наблюдал у русских старообрядцев в Польше Михал Глушковски (2012). В отличие от Глушковского автор статьи расширяет рамки понятия «смешение кодов» и приходит к выводу, что из исследуемых говоров на данный момент, по всей вероятности, развились смешанные идиомы (fused lects), как их определяет Петер Ауэр (1999).

Ключевые слова: славянские переселенческие говоры в России, языковой контакт, межъязыковая интерференция, переключение и смешение кодов, смешанный идиом 